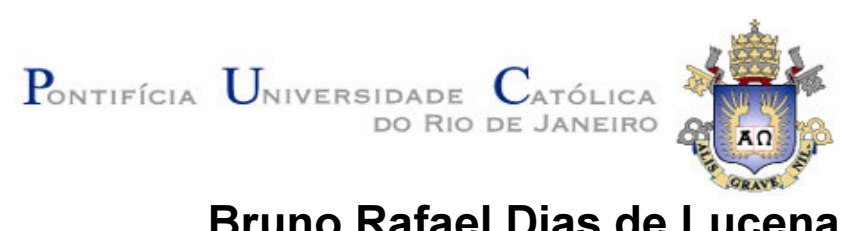

Bruno Rafael Dias de Lucena

\title{
Avaliação de Recursos de Petróleo não Descobertos: \\ Metodologia e Métodos de Eliciação de Informações \\ Subjetivas
}

\section{Dissertação de Mestrado}

Dissertação apresentada como requisito parcial para obtenção do título de Mestre em Gerência de Produção pelo Programa de Pós-Graduação em Engenharia Industrial da PUC-Rio.

Orientador: Leonardo Junqueira Lustosa

Rio de Janeiro, 07 de abril de 2006 


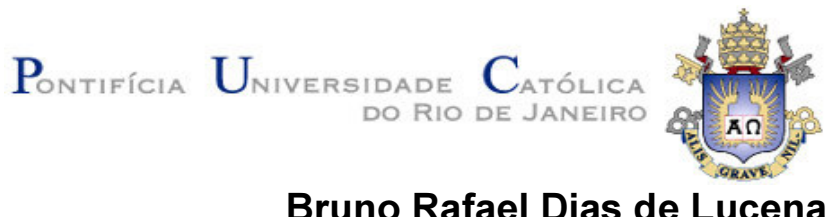

\section{Avaliação de Recursos de Petróleo não Descobertos: Metodologia e Métodos de Eliciação de Informações Subjetivas}

Dissertação apresentada como requisito parcial para obtenção do título de Mestre em Gerência de Produção pelo Programa de Pós-Graduação em Engenharia Industrial da PUC-Rio. Aprovada pela Comissão Examinadora abaixo assinada.

Prof. Leonardo Junqueira Lustosa Orientador Departamento de Engenharia Industrial -PUC-Rio

Prof. Eugenio Kanh Epprecht Departamento de Engenharia Industrial -PUC-Rio

Prof. Antonio Fernando Castro Vieira Departamento de Engenharia Industrial - PUC-Rio

Prof. José Eugenio Leal Coordenador Setorial do Centro Técnico Científico - PUC-Rio 
Todos os direitos reservados. É proibida a reprodução total ou parcial do trabalho sem autorização da universidade, do autor e do orientador.

\section{Bruno Rafael Dias de Lucena}

Graduou-se em Engenharia de Produção na Universidade do Estado do Pará em 2003.

Ficha Catalográfica

Lucena, Bruno Rafael Dias de

Avaliação de recursos de petróleo não descobertos; metodologia e métodos de eliciação de informações subjetivas / Bruno Rafael Dias de Lucena; orientador: Leonardo Junqueira Lustosa. Rio de Janeiro : PUC, Departamento de Engenharia Industrial, 2006.

$$
83 \text { f. : il. ; } 30 \mathrm{~cm}
$$

Dissertação (mestrado) - Pontifícia Universidade Católica do Rio de Janeiro, Departamento de Engenharia Industrial.

Inclui referências bibliográficas.

1. Engenharia industrial - Teses. 2. Petróleo. 3. Avaliação de reservas. 4, Recursos não descobertos. 5. Probabilidade subjetiva. 6. Eliciação de informações. I. Lustosa, Leonardo Junqueira. II. Pontifícia Universidade Católica do Rio de Janeiro. Departamento de Engenharia Industrial. III. Título. 
À minha amada esposa Lílian. À minha mãe Alice. 


\section{Agradecimentos}

Ao meu orientador professor Leonardo Lustosa pelo grande apoio no desenvolvimento desta dissertação, e pela sua sincera amizade.

A CAPES e a Pontifícia Universidade Católica do Rio de Janeiro, em especial ao Departamento de Engenharia Industrial da PUC - Rio, pelo efetivo apoio, pois sem este seria impossível a realização deste trabalho.

Aos Srs. Cleomar e Luciano, funcionários da Petrobrás pelo material de apoio cedido, sem o qual a riqueza desta dissertação poderia ser comprometida.

Aos Professores e Funcionários do Departamento Industrial da PUC-RIO, por tornarem possível minha formação na Pós-Graduação.

Aos colegas da Pós-Graduação, pelo companheirismo e apoio, em especial ao conterrâneo Leonardo Pedreira.

À minha família, amigos e todos aqueles que, apesar da distância, torceram por mim, gostaria de registrar minha especial gratidão. 


\section{Resumo}

Lucena, Bruno Rafael Dias de. Avaliação de Recursos de Petróleo não Descobertos: Metodologia e Métodos de Eliciação de Informações Subjetivas. Rio de Janeiro, 2006. 83p. Dissertação de Mestrado Departamento de Engenharia Industrial, Pontifícia Universidade Católica do Rio de Janeiro.

A avaliação de recursos petrolíferos não descobertos, isto é feita a partir de informações obtidas de testes indiretos como a sismografia, é a base para as decisões sobre a perfuração de poços de exploração. As informações disponíveis nessa fase que antecede a perfuração de poços são vagas e plenas de incertezas. Por outro lado, a avaliação econômica cuidadosa dos prospectos nessa fase é fundamental para as decisões relativas às fases seguintes, principalmente, devido ao elevado custo da perfuração de poços que nelas ocorrem. Por isso, a aplicação de métodos estatísticos que reduzam as incertezas na avaliação de recursos não descobertos é de grande importância para a rentabilidade das empresas de petróleo. O cálculo do volume recuperável de hidrocarbonetos (base para a avaliação econômica) depende avaliações feitas por especialistas e para considerar as incertezas inerentes aos dados as avaliações devem ser representadas probabilisticamente. O objetivo desta dissertação é rever as metodologias e técnicas formais para avaliação probabilística de recursos não descobertos encontradas na literatura, tendo sempre em mente os aspectos práticos de implementação. A descrição destas metodologias inclui a estrutura e a organização necessárias para gerenciar o trabalho dos especialistas, a eliciação de distribuições de probabilidades subjetivas e a combinação destas distribuições, além de técnicas para verificação de consistência das avaliações e redução de vieses. São feitas considerações sobre as principais distribuições de probabilidade usadas para representar incertezas inerentes à avaliação de fatores geológicos. Cada uma das metodologias e técnicas é exemplificada e discutida. Uma planilha eletrônica foi constituída com objeto de ilustrar os métodos apresentados e servir como protótipo de instrumento de apoio a avaliação probabilística de fatores geológicos.

\section{Palavras-chave}

Petróleo; Avaliação de reservas; Recursos não descobertos; Probabilidade subjetiva; Eliciação de informações 


\section{Abstract}

Lucena, Bruno Rafael Dias de. Assessing Undiscovered Oil and Gas Resources: Methodology and Elicitation of Subjective Information. Rio de Janeiro, 2006. 83p. M. Sc. Dissertation - Departamento de Engenharia Industrial, Pontifícia Universidade Católica do Rio de Janeiro.

The evaluation of not discovered oil and gas resources, that uses solely information obtained from indirect tests such as seismography, is the base for the decisions on the drilling exploration wells. The information available in this phase that precedes the drilling of wells is vague and very uncertain. On the other hand, the careful economic evaluation of the prospects in this phase is very important for the decisions concerning the following phases, mainly on because of the high cost of the drilling of wells that occur. Therefore, the application of statistical methods for reducing the uncertainties and biases in the evaluation of undiscovered resources is quite important for the oil companies. The calculation of the recoverable volume of hydro-carbons (the basis for economic evaluation) depends on assessments made by experts, and for representing the uncertainties; the data must be probabilistically distributed. The objective of this thesis is to review the formal methodologies and techniques for probabilistic evaluation of undiscovered resources founded in literature, having always in mind the practical aspects of implementation. The description of these methodologies range from the definition of the structure and organization necessary to manage the work of the experts, the elicitation of distributions of subjective probabilities and the combination of these distributions, until techniques for verification of evaluations consistency and reduction of biases. Some considerations are made about the main distributions of probability used for representing the uncertainties in evaluations of geologic factors. Each methodology and technique is illustrated and discussed. An electronic spread sheet was developed to illustrate the presented methods and as a prototype of computer aid for the probabilistic evaluation of geologic factors.

\section{Keywords}

Oil and gas; Assessment of reserves; Undiscovered resources; Subjective probability; Elicitation of Information 


\section{Sumário}

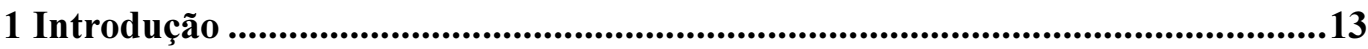

1.1 Contextualização e Justificativa da Pesquisa ...............................................13

1.2 Problema de Pesquisa e Objetivo de Trabalho .............................................15

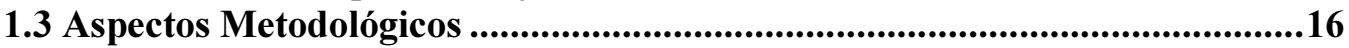

1.4 Limitações de Campo e Enfoque mais Importantes ........................................17

1.5 Estruturação da Dissertação.........................................................................17

2 O Processo de Avaliação de Recursos de Petróleo não Descobertos ...................19

2.1 Definiçãa de Estrutura Geológica........................................................................21

2.2 Cálculo do Volume de Hidrocarbonetos........................................................22

3 Preparação para o Processo de Avaliação.................................................................24

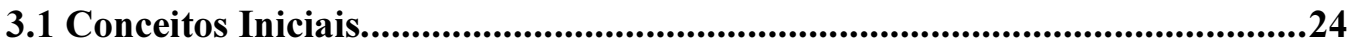

3.2 Definiç̧ão do Objeto de Análise..........................................................................26

3.3 Escolha da Equipe de Avaliadores...................................................................26

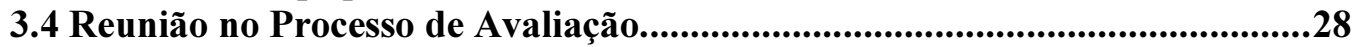

3.5 Motivação, Treinamento e Calibração ..........................................................29

3.6 Definição do Proceso (tipo e nível de detalhe da informação) .......................31

3.7 Eliciação das Probabilidades Subjetivas ...................................................32

3.8 Elaboração do Questionário Apropriado ........................................................33

4 Eliciação de Probabilidades .......................................................................35

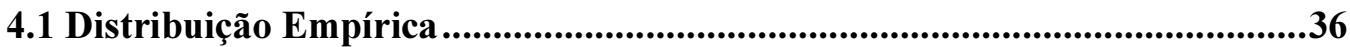

4.2 Distribuição Lognormal...........................................................................39

4.3 Distribuição Triangular .........................................................................................42

4.4 Distribuição Beta....................................................................................44

4.5 Eliciação de Distribuições de Probabilidades Subjetivas..................................47

4.6 Identificação de Vieses ..........................................................................................50

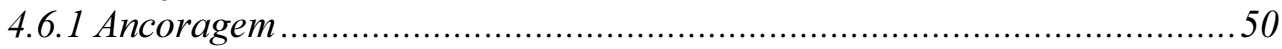

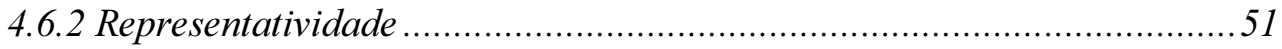

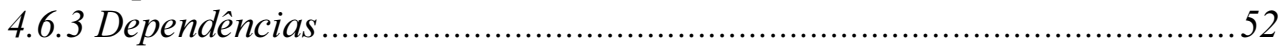

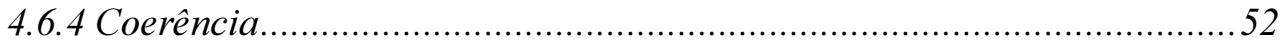

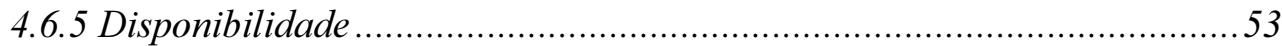

4.7 Especificação da Incerteza Geológica...................................................53

4.8 Interação Permitida entre Especialistas ....................................................57

4.9 Quantidade e Tempo entre Feedbacks ................................................58

4.10 Documetação da Informação ...................................................................58

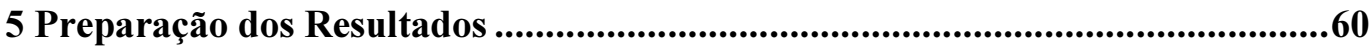

5.1 Abordagem Matemática para Combinação de Probabilidades.....................61

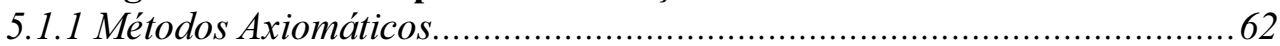

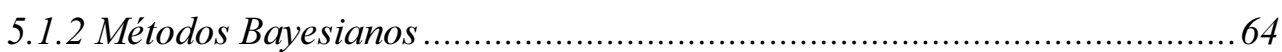

5.2 Abordagem Matemática para Combinação de Distribuição de Probabilidades .................................................................................................68 


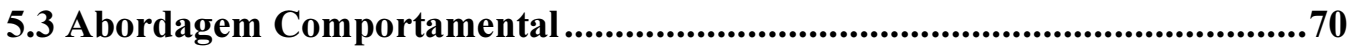

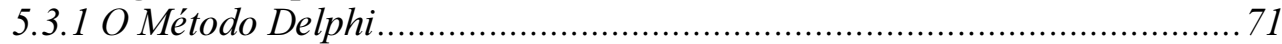

5.4 Suporte ..............................................................................................................72

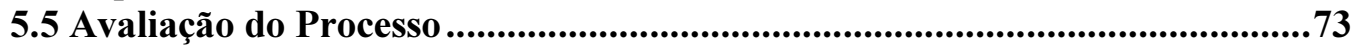

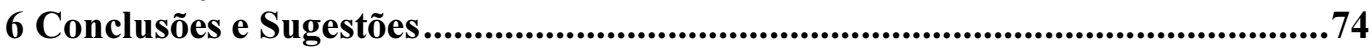

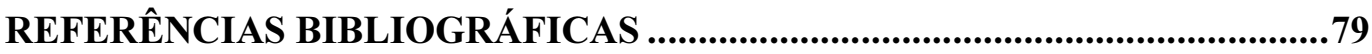

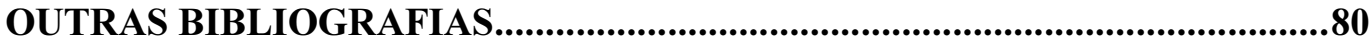

ANEXO I - Formulário de Avaliação de Parâmetros .........................................82

ANEXO II - Avaliação de Recursos Não Descobertos de com Método Delphi ....83 


\section{Lista de Figuras}

Figura 2.1 - Fases do processo de exploração dos recursos não descobertos ......21

Figura 4.1 - Gráficos das distribuições empíricas dos parâmetros geológicos ....37

Figura 4.2 - Distribuição lognormal da área do play ..........................................41

Figura 4.3 - Distribuição triangular ...............................................................43

Figura 4.4 - Método da bisecção (passo 1) ......................................................48

Figura 4.5 - Método da bisecção (passo 2) .....................................................48 


\section{Lista de Quadros}

Quadro 3.1 - Diferenças entre avaliações esportivas e geológicas .......................30

Quadro 4.1 - Características do sistema geológicos e percentis eliciados.............37

Quadro 4.2 - Classes da distribuição da espessura do reservatório.......................38

Quadro 4.3 - Percentis da distribuição lognormal ..............................................4

Quadro 4.4 - Lista de checagem para análise de fatores geológicos ....................54

Quadro 4.5 - Formulário de avaliação de probabilidades de fatores geológicos...54

Quadro 4.6 - Histórico de ocorrência dos fatores geológicos ..............................55

Quadro 4.7 - Probabilidade de ocorrência dos fatores geológicos .......................56

Quadro 5.1 - Histórico das avaliações dos especialistas....................................65

Quadro 5.2 - Parâmetros da distribuição normal equivalente..............................68 
“... Em si apenas ouvia o eco daquelas palavras que lhe ditavam o futuro. Tudo era tão vago, tão incerto... Não sabia lidar com a incerteza, e agora ela fazia parte de si..."

Maria Branco 